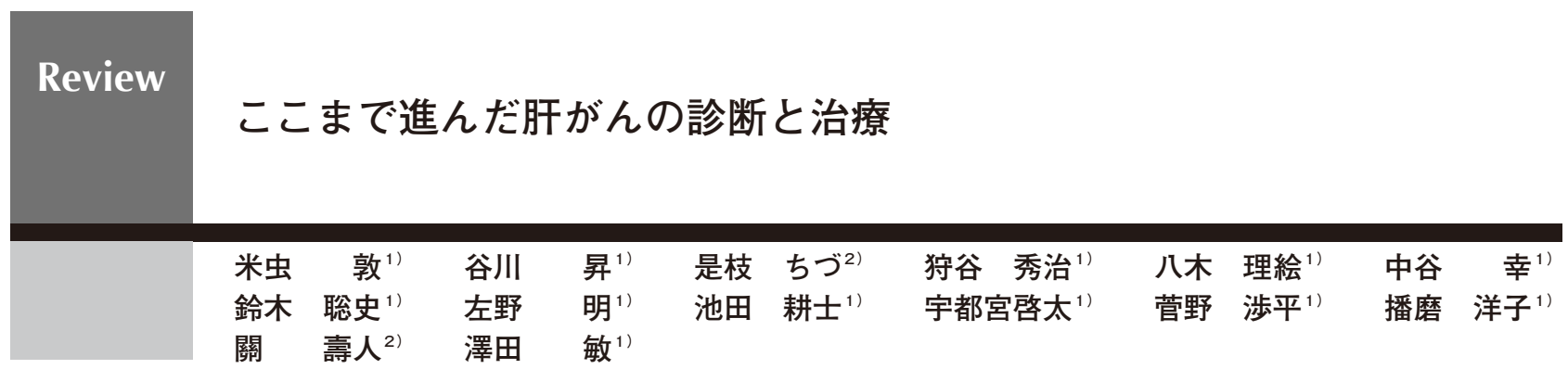

\title{
Recent diagnosis and therapy for liver cancer
}
Atsushi Komemushi"), Noboru Tanigawa", Chizu Koreeda²), Shuji Kariya", Rie Yagi"), Sachi Nakatani",

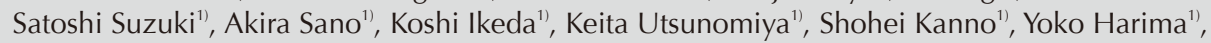 Toshihito Seki ${ }^{2}$ and Satoshi Sawada ${ }^{1}$

\begin{abstract}
This review described diagnosis and treatment of hepatocellular carcinoma. Hepatocellular carcinoma commonly develops in patients with chronic hepatitis caused by hepatitis C and hepatitis B virus. Ultrasound imaging, computerized tomography and magnetic resonance imaging are useful for disclosing hepatocellular carcinoma. Surgical resection, percutaneous needle therapy, transarterial therapy and systematic chemotherapy are used to treatment of hepatocellular carcinoma.
\end{abstract}

Key words: liver cancer, hepatocellular carcinoma, diagnosis, treatment, hepatitis

Accepted on Feb. 25, 2011

関西医科大学放射線科 ${ }^{1)}$, 消化器肝臓内科 ${ }^{2)}$ 个570-8507 大阪府守口市文園町10-15

Department of Radiology, Gastroenterology and hepatology, Kansai Medical University

Address: 10-15, Fumizono-cho, Moriguchi-city, Osaka, 570-8507, Japan 


\section{はじめに}

本稿は第29回Microwave Surgery研究会, 関西医科大 学附属滝井病院肝疾患センター, 大阪府肝疾患診療連携 拠点病院連絡協議会の共催にて平成 22 年 9 月 4 日に開催 された市民公開講座（テーマ：消化器がん・肝臟がんの 診断と治療）より『ここまで進んだ肝がんの診断と治療』 の講演要旨をまとめたものです.

\section{肝臓のはたらき}

「肝臓」はみなさんの右胸の下あたりにある臟器です。 栄養分の生成, 譻蔵, 代謝の働き, 血液中のホルモン, 薬物, 毒物などの代謝や解毒の働き, 出血を止めるため の蛋白の合成, 胆汁の産生と胆汁酸の合成, 身体の中に 侵入したウイルスや細菌感染を防御するなどの働きが あり, 我々が生きていくためにとても大切な働きをして います1)2).

\section{肝臓がんと肝疾患の死亡率}

我が国の平成19年の死因順位別死亡数·死亡率では 『悪性新生物（がん）』での死亡率は男女を問わず 1 位で す，中でも肝臓がんは，悪性新生物の主な部位別死亡率 で男性では第 3 位，女性では第 4 位となっており，また， 本講演が行われた関西地方は肝臟がんでの死亡率が全国 でも特に高い地域の一つです。

しかし，これとは別に『肝疾患』による死亡率も男性 で 8 位, 女性で11位, 総数で 9 位の死因です. 肝がんの 診断と治療を考える際には, がんを治療することだけで なく, 肝臟自体の機能についても十分な配慮をしていく 必要があります。

\section{肝臟がんの種類}

肝臓にできるがんは，肝臓にできた「原発性肝がん」 と他の臓器から転移した「転移性肝がん」に大別されま す．原発性肝がんには「肝細胞がん」「胆管細胞がん」な どがありますが，我が国では原発性肝がんの $90 \%$ が肝細 胞がんであり ${ }^{3)}$, 本稿では肝細胞がんのことを中心に解 説をしていきます.

\section{肝臓がんの背景病変}

我が国では，肝細胞がんの約70\%はC型肝炎ウイルス が原因であり, 約 $20 \%$ は型肝炎ウイルスの感染が原因 となっています，肝蔵がんについて理解するには，これ らの肝炎ウイルスについての理解が必要です.

B型肝炎ウイルスは，主に血液や体液を介して感染す るウイルスです，注射針の使い回しや輸血, 性交渉や出 産（現在ではワクチンの使用で母子感染予防が行われて います）などによって感染します，我が国の2000年時点 での15 69歳まで国民のうち, 約 $1 \%$ の方が自覚しない ままB型肝炎ウイルスに感染していると推計されていま $す^{11}$.

C型肝炎ウイルスも, 主に血液や体液を介して感染す るウイルスです．注射針の使い回しや適切な消毒を行わ ずに入れ墨やピアスの穴開けなどをした場合, 輸血など によって感染します. 性交涉や出産で感染することは稀 です．我が国の 2000 年時点での15～69歳まで国民のうち 約 $1 \%$ の方が自覚しないままC型肝炎ウイルスに感染し, また70歳以上では約 $3 \%$ の方が自覚しないままC型肝炎 ウイルスに感染していると考えられています2).

肝炎ウイルスに持続して感染すると, 慢性肝炎という 状態から肝臓の線維化が進み, やがては肝硬変に至りま す. C型慢性肝炎が肝硬変まで進行すると, 今後10年間 に肝臟がんが発生する確率は70\%になります，B型慢性 肝炎も肝硬変になると 10 年間で約 $30 \%$ 肝がんを発生する と考えられています ${ }^{4}$. このため肝臓がんを予防するに は, B型肝炎ウイルス，C型肝炎ウイルスの感染をできる だけ早く診断し，治療により肝炎の進行を予防し，たと え肝臓がんが発生しても早期に発見することが重要です。

肝炎ウイルスの感染は全く症状がないことが多いため, 診断は血液検査で行います。この血液検査は, 一般的な 医療機関で行うことができます。肝炎ウイルスへの感染 が確認されれば，その状況に応じて様々な治療が行われ ます。

\section{肝臓がんの早期発見のための検査}

肝炎ウイルスに感染して慢性肝炎になっている方は, 肝臓がんが非常に発生しやすい状態です，肝臓がんをで きるだけ早期に発見するために様々な検査を行います。 


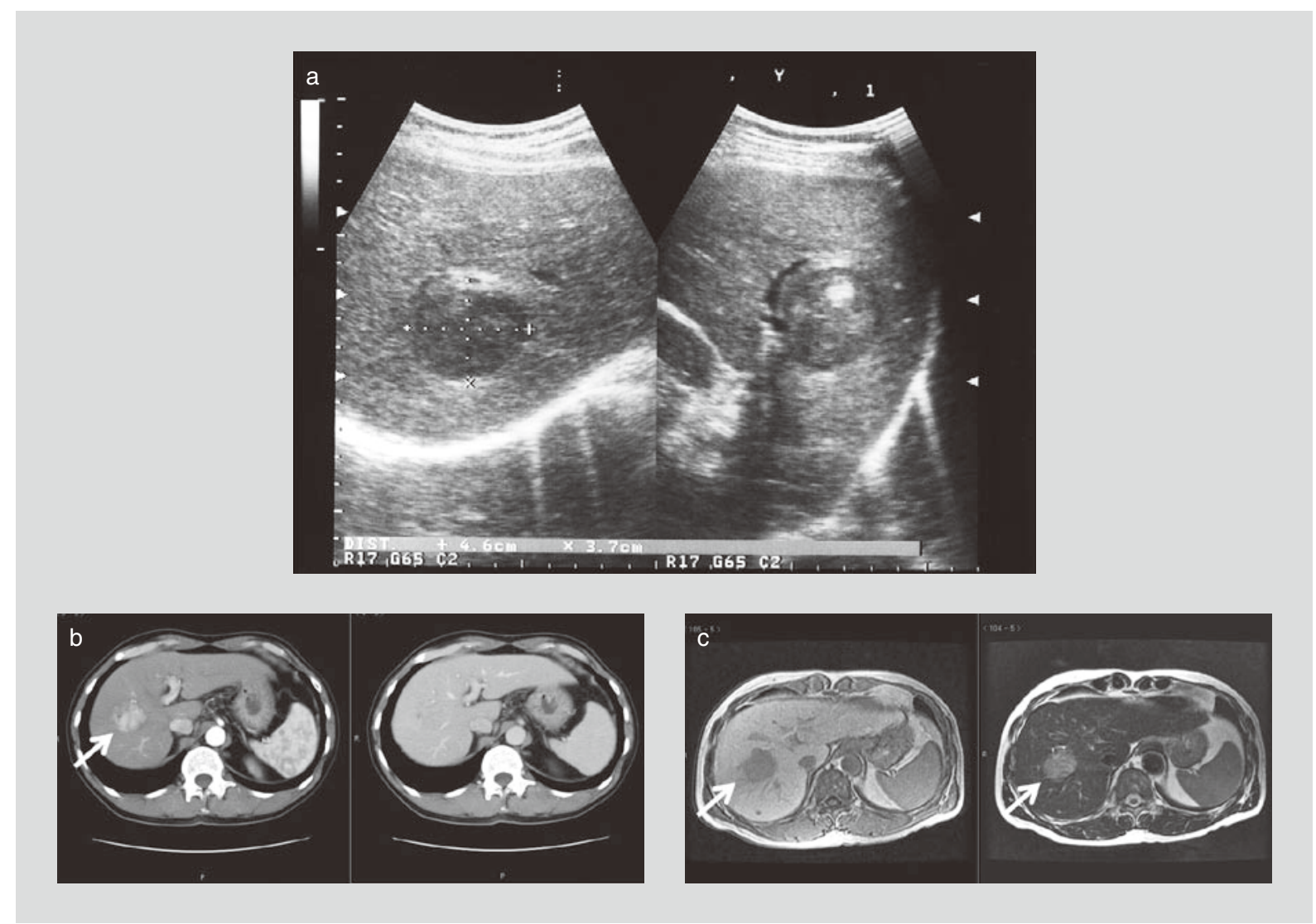

\section{Figure 1}

a: Ultrasound imaging (US)

b: computerized tomography (CT)

c: Magnetic Resonance Imaging (MRI)

US, CT and MRI disclosed a liver nodule in S7, suggesting nodular hepatocellular carcinoma.

\section{1. 血液検查}

GOT, GPT（AST, ALT）は, 肝細胞が破壊されると血 液の中に流れ出てくる酵素です．肝細胞がどれくらい障 害されているのか, 炎症の程度を知ることができます5). 血小板は，血を固める作用がある血球成分です．慢性肝 炎や肝硬変が進行すると血小板の数が減ってきます．特 にC型肝炎では，血小板が 15 万 $/ \mathrm{mm}^{3}$ 以下になると肝臟が んが発生する可能性が高まります5).

アルブミン (Alb) は, 肝臟で作られる蛋白質です。肝 臓の機能が悪くなると低下し，さらに低下するとむくみ や腹水が出現します ${ }^{5}$.

総ビリルビン（T-Bil）は, 肝細胞が障害されると上昇 し, 皮膚や白目が黄色くなる症状が出ます5).
AFP（アルファ・フェト・プロテイン）とPIVKA-II （ピブカ・トゥー）は, 肝細胞がんの時に上昇する腫瘍 マーカーです，無症状の時でもAFP, PIVKA-II が上昇 して肝細胞がんを診断できることがあります5).

\section{2. 腹部超音波検査（腹部エコー）（Fig. 1a）}

超音波診断装置を使って肝臓の中を見る検査です，肝 細胞がんの発見に非常に有用であり, 進行した慢性肝炎 や肝硬変では 3 カ月ごとに検査することが推奨されてい ます5).

\section{3. 腹部CT検查 (Fig. 1b)}

X線を使用して体の中の写真を撮る検査です，造影剤 
を注射することによって，血流が豊富な肝臟がんを詳し く診断することができます.

\section{4. 腹部MRI検查 (Fig. 1c)}

磁場を使用して体の中の写真を撮る検査です．X線へ の被曝がなく，造影剤の注射を併用することで肝臓がん を詳しく診断することができます，最近になって，肝細 胞がんをさらに明瞭に映し出す造影剤が使用されるよう になりました。

\section{肝臟がんの進行度と治療方針}

肝臓がんの治療方針を判断するには，がんの数と大き さ, 他の臓器への転移の有無, 肝機能などをみて判断し ます。進行した慢性肝炎や肝硬変の状態に肝臓がんが発 生することが多いため, 肝臓がんの状態だけでなく, 肝 機能も併せて総合的に判断することが重要です。

\section{肝臟がんの治療}

\section{1. 外科治療}

手術によって, がんとその周囲の肝組織を取り除きま す．従来は開腹して行われていましたが，最近では腹腔 鏡を用いた手術が行われることもあります．肝臓がんが 1 つで $5 \mathrm{~cm}$ 以下または $3 \mathrm{~cm}$ 以下で 3 個以内ならば, ド ナーからの肝移植が行われることもあります.

\section{2. 局所治療}

肝臓がんに特殊な針を刺し，エタノールを注入したり， ラジオ波やマイクロ波と呼ばれる電気を利用したりして 肝臓がんとその周囲の肝組織を壊死させる方法です。

\section{腹部血管造影（経カテーテル的肝動脈塞栓療法）（Fig. 2)} 太ももの付け根からカテーテルと呼ばれる直径 $1 \mathrm{~mm}$ 程度の細い管を挿入し, 造影剤でお腹の血管の写真を撮 影して肝蔵の血管を確認します．肝蔵がんへ行く血管に カテーテルを送り込んで, 抗がん剂を直接に肝臓がんの 栄養血管に注入します。 その後, ゼラチン性の細かいス ポンジで肝臓がんへ行く血管を目詰まりさせ，肝臓がん に血液が行かないようにして肝臓がんを「兵糧攻め」に します。

\section{3. リザーバーによる抗がん剤動注化学療法}

頻回に肝臓に抗がん剂を注入するために, 肝臓の血管 にカテーテルを埋め込む方法です. 目的の血管に簡単に 抗がん剂を注入することができるようになり, 外来で抗 がん剤の注入をすることも可能になります.

\section{4. 全身化学療法}

最近になって，血管の新生を抑制する分子標的薬が肝 臓がんに使用できるようになりました，飲み薬を飲むこ とによって, 肝蔵がんの増悪を抑制することができます.

再発のチェック

上記の治療によって局所の肝臓がんが治っても, 元々 の慢性肝炎は残るため, 肝臓がんの再発率は非常に高い です，根治したとしても，年に $15 〜 20 \%$ と高い割合で再 発し，5年再発率は約 $80 \%$ と言われています。 そのため, 定期的な再発のチェックが必要で, また肝炎に対する治 療も必要です.

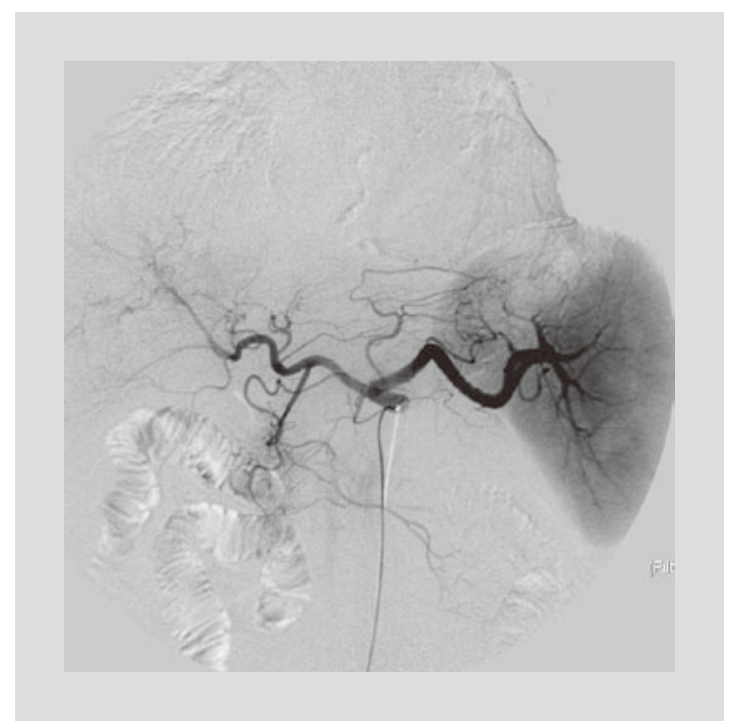

Figure 2 Abdominal angiography

Angiography of celiac artery was performed before transarterial chemoembolization for hepatocellular carcinoma. 


\section{最後に}

肝臟がんや肝炎ウイルスの感染, 慢性肝炎, 肝硬変など
を診断された場合は決して放置せず，担当医の勧めに従っ て定期的な検查や治療を受けるように心掛けて下さい.

\section{References}

1) 厚生労働省：B型肝炎について（一般的なQ\&A）平成18年 3 月改訂（改訂第 2 版）。厚生労働省健康局結核感染症課，1-45，2006

2）厚生労働省：C型肝炎について（一般的なQ\&A）平成18年 3 月改訂（改訂第 6 版）。厚生労働省健康局結核感染症課，1-36，2006

3）国立がんセンターがん対策情報センター：各種がんシリーズ肝細胞がん．国立がんセンターがん対策情報センター，1-19，2010

4) 社団法人日本肝臟学会：慢性肝炎理解のための手引き。社団法人日本肝臟学会企画広報委員会, 1-14, 2007

5 ）社団法人日本肝臟学会：肝がん撲滅のために。社団法人日本肝臟学会企画広報委員会，1-9，2007 